\title{
Post-Talilban Afghanistan:
}

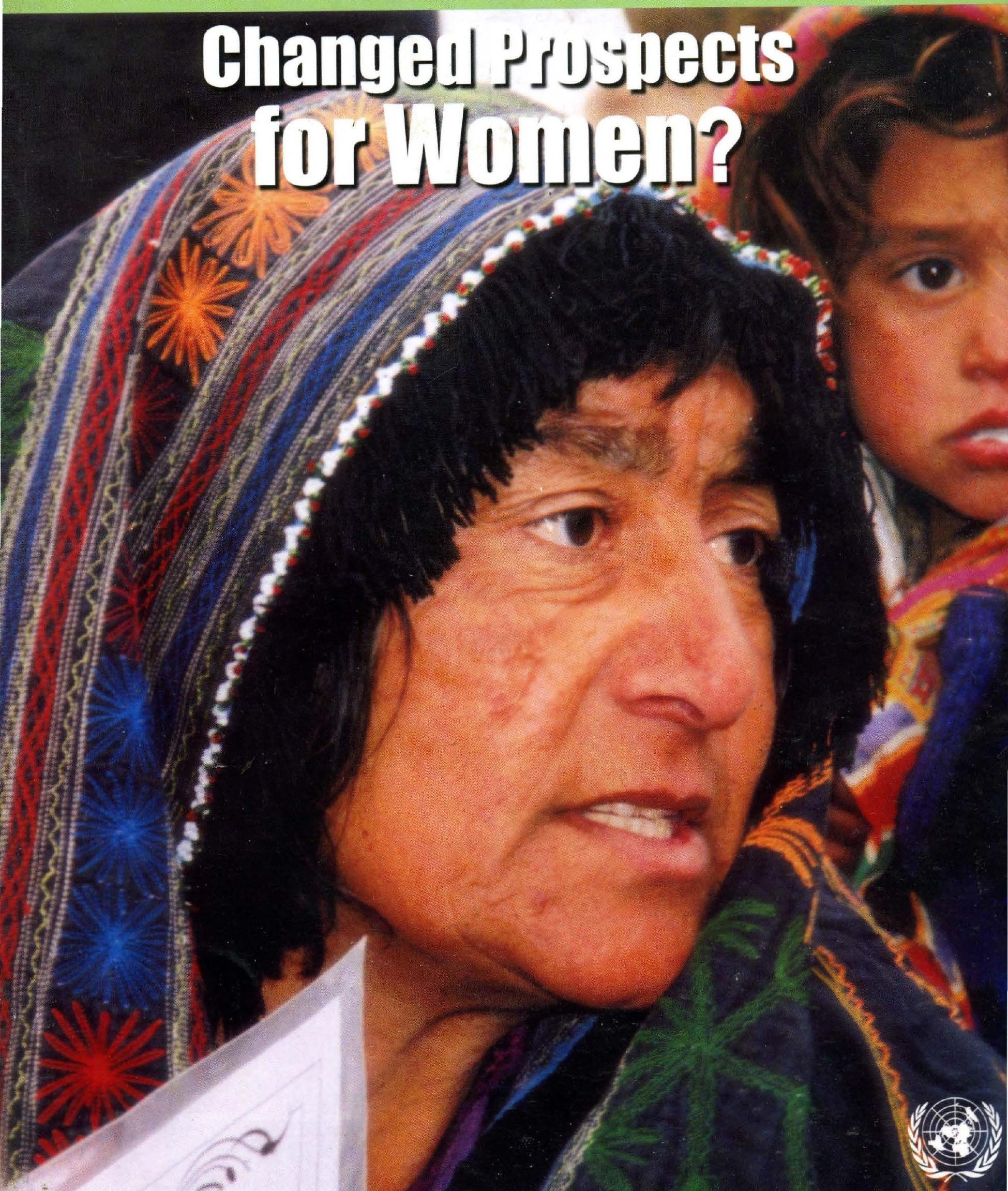




\section{TABLE OF CONTENTS}

Preface

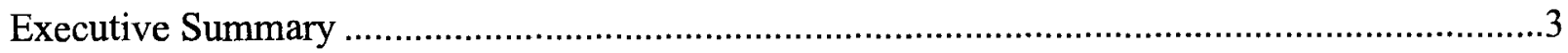

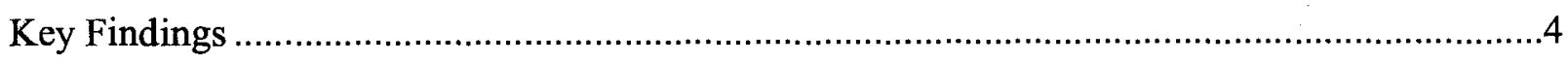

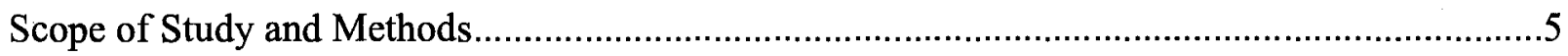

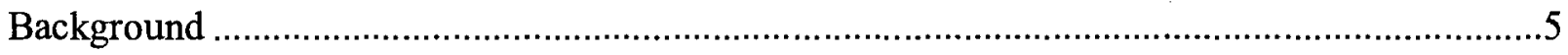

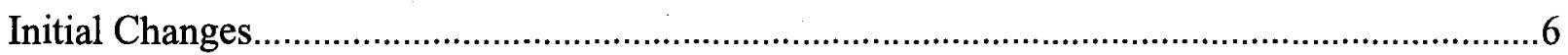

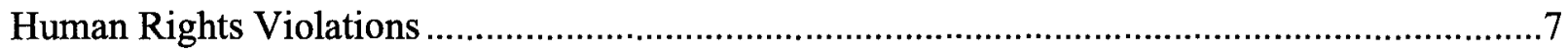

Trafficking \& exploitation of children ......................................................................

Violence against women and girls: addressing their fears ................................................8

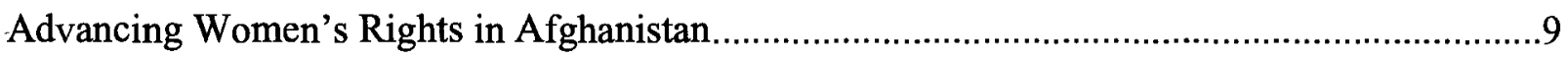

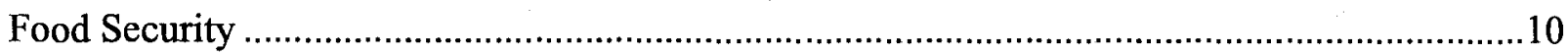

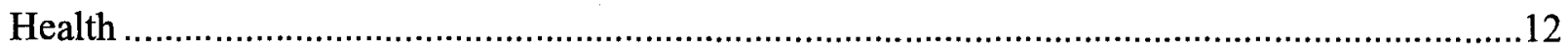

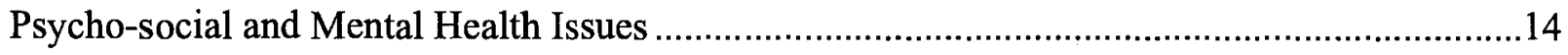

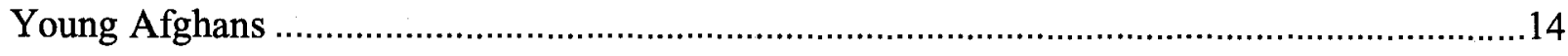

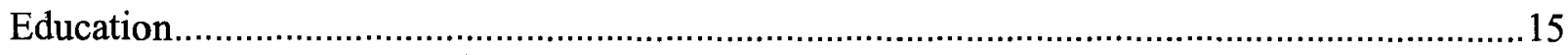

Internally Displaced Persons and Refugees ………….......................................................16

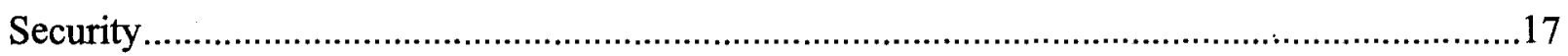

Prospects for Gender Equity and Progress by UN agencies .................................................17

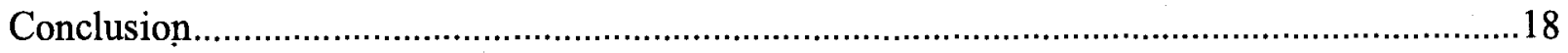

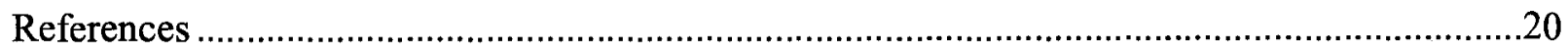

ANNEXES

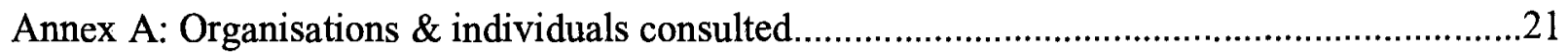

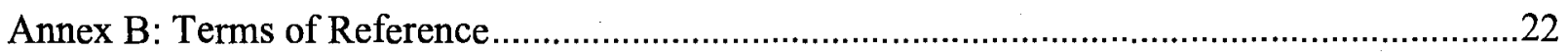




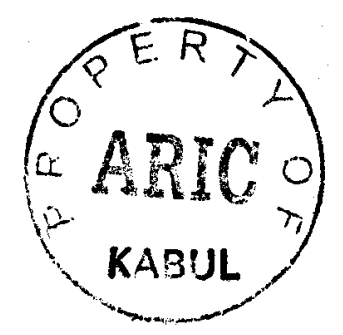

For further information and additional copies, please contact

Human Rights Advisor's office

United Nations Coordinator's Office for Afghanistan

Kabul:

Tel: (92 51) 2214522

Fax: (92 51) 2214379

Islamabad:

Tel: (92 51) 2211451

Fax: (92 51) 2211450

This document can also be found on: http://www.pcpafg.org 


\section{ACKNOWLEDGEMENTS}

The author wishes to acknowledge, with appreciation, all the people who kindly took time to be interviewed and provide their insights to this study commissioned by the UN Coordinator's Office. Special thanks to the many UNCO colleagues who helped, including regional staff in Herat and Kabul, as well as the HR Advisor who provided support throughout this project.

Cover Photo: Norah Niland, UNCO

Printed: The Army Press Rawalpindi. 5562939 - 5563060 


\section{Preface}

Given the extreme abuse imposed on Afghan women by the Taliban regime during the last six years both international and local initial reactions were jubilant and full of hope for Afghan women when the Taliban were ousted from power. For more than 22 years women in Afghanistan have not felt safe. Even now in post-Taliban Afghanistan they are still afraid. I interviewed a number of women in Kabul and Herat about their fears: "Who are you afraid of?" "The men with the guns," they all responded.

This study focuses on the situation for women after the Taliban. However, without security no one in Afghanistan will be safe, especially women and girls. Women who were victimized by all warring factions during the mujahidin period (1992-1996) and under the Taliban understand what is at stake.

\section{Executive Summary}

The primary objective of this study was to examine the extent to which the events following the 11 September 2001 attacks on the United States impacted on the lives of women and girls in Afghanistan. The most striking change was the removal of the Taliban from power. The severe restrictions imposed by the Taliban, by and large, disappeared with the departure of their regime. Afghans interviewed described feelings of hope and relief. They typically responded: "It is like being freed from prison." "Now there is hope for a future for my children."

The prospects for improving the lives of women in post-Taliban Afghanistan cannot be taken out of context and should be viewed holistically. This report highlights a range of issues that at first glance may not appear to be directly related to women. Women are the predominant social category in Afghanistan, estimated to comprise 55 percent or more of the population. Therefore all sectorsagriculture, health, education, economic development, water, sanitation, mine action, and drug control-affect women. Solutions to many of the problems Afghan women and girls face will come by addressing gender issues in every aspect of social, political and economic life.

A significant finding from this study was the urgent need to establish a nationwide professional security force - a strategy essential to the survival of peace and the potential for reconstruction, development and realization of fundamental human rights in Afghanistan. Security is a key issue for women. Women in Afghanistan have lived in fear for more than two decades-most hardly remember when they felt personally secure.

The resurgence of poppy growing is another post-Taliban phenomenon with potential to undermine recovery efforts. Afghanistan's role as a major source of the world's supply of heroin cannot be ignored. Not only does the drug trade supply the money drawing card that attracts criminal elements and perpetuates internal corruption, but the elaborate covert system associated with illicit drugs could keep terrorist groups and sympathizers engaged in Afghanistan for some time. In spite of the urgent need for economic recovery in the agricultural sector poppy farmers must be encouraged to switch to substitute crops, even if at great cost to donors and international partners, to provide both incentives and disincentives.

The dire conditions faced by most Afghan women are due to the accumulated and combined effects of 23 years of unrelenting war, persistent human rights violations, drought, and the Taliban regime. Women welcome the end of fighting but with some skepticism about the immediate future and the prospects for lasting peace. 


\section{Key Findings}

- Widespread fear for their personal safety is a common concern of women in urban centers and on the roads. Women in towns, as well as in rural areas, continue wearing the burqa as protection even after the ousting of the Taliban.

- Severe food insecurity is a problem especially among vulnerable groups such as widows, elderly and the disabled.

- Inequitable access to food by women in the internally displaced persons (IDP) camps has led to serious malnutrition among female-headed households and their children. Women in the IDP camps are not represented in camp leadership committees and therefore do not have a mechanism to express their needs and interests. Implementing agencies report that "mafias" run the camps by controlling food and access to services.

- Women suffer from post-traumatic stress syndrome and depression as a result of life under the Taliban, over two decades of war, and accumulated personal loss.

- Self-medication among women to treat chronic depression and insomnia is a common practice. Women purchase tranquilizers and other drugs in the bazaars.

- Social withdrawal and hopelessness among young people is found in all economic categories.

- Women have major health problems. Countrywide shortages of basic medicines, lack of transportation, and access to health care, result in continued high maternal and infant mortality in every province but the situation is worse in rural areas.

- Women do not report sexual abuses because of shame and fear of rejection by their husbands and families.

- Reluctance on the part of girls who missed five or more years of schooling to return to classes with young children.

- Legal issues pertaining to women - access to land, inheritance, passport requirements, and matrimonial laws and customs, among others - need urgent attention.

- Violence against women continues at an alarming rate both in rural and urban areas.

- Some rural women are demonstrating new independence by insisting it is their right to participate in training programs and income generating schemes offered by non-governmental organizations (NGOs) without obtaining permission from their husbands, fathers or local commanders as was the case until recently. NGO workers suggest that even rural women have been emboldened by the demise of the Taliban and the new environment.

- Many women feel optimistic about the future and are willing to learn new and non-traditional skills. 


\section{Scope of Study and Methods}

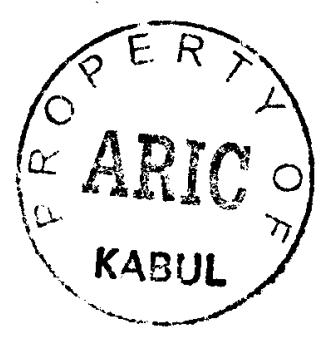

The downfall of the Taliban regime late in 2001 brought a dramatic change in the political landscape of Afghanistan. This study examined the immediate changes that occurred and explored the potential for future changes emanating from the change in power with the removal of the repressive Taliban regime and the installation of the Afghanistan Interim Administration (AIA). The objective of this study was to identify changes affecting the lives of women and girls that occurred as a result of the new political landscape. Additionally, the research sought to assess contemporary realities that shape the lives of women and girls and to identify opportunities, as well as obstacles, in the paths of women.

This study does not purport to be a comprehensive research endeavor. This report presents a snapshot of life for women and girls in Afghanistan shortly after the end of the Taliban regime. The scope of this study does not permit an in-depth discussion of the political history or of Afghan culture. For more substantive background information the interested reader can consult an extensive body of literature on Afghanistan, as well as the reports and books noted in the bibliography. Constraints on this study such as time, resources-including shortages of vehicles and drivers-and security concerns limited the scope of the research carried out during the early period of the transition from war to peace.

The research took place from 1-28 January 2002. The consultant conducted interviews and attended meetings with representatives of the United Nations agencies, international and national nongovernmental organizations, representatives of the Afghan Interim Authority (AIA), internally displaced persons (IDPs) and with a cross section of Afghans living in their respective home areas. The list of organizations consulted for the study may be found in Annex A. The names of Afghan private citizens who were interviewed have been omitted to respect their privacy. The Terms of Reference may be found in Annex B. The sites visited by the consultant were Kabul, Herat, Peshawar and Islamabad.

The research employed standard anthropological methods including structured and unstructured interviews, focus group discussions with targeted social categories, and a review of recent literature, including aid agency reports generated from January 2001 through January 2002. The study did not include formal surveys. The research employed a qualitative rather than quantitative approach. Most examples are anecdotal but useful in that they highlight the need for further research and they illustrate particular issues. Whenever possible, data that was presented was verified using a method of triangulated inquiry - posing the same question to three different sources. The analysis is that of the author's and does not necessarily reflect the views or policy of the Office of the UN Coordinator.

\section{Background}

Since September 1996 when the Taliban entered Kabul and expanded their power base over most of the country, they placed women at the forefront of their campaign to convert Afghanistan to their version of a pure Islamic fundamentalist nation. During their regime women and girls were not allowed to go to school or university, women could not work, or leave the house without a male relative escort, or show their faces in public. They were forced to wear the burqa, a tent-like garment 
that covers from head-to-toe. The economic, social and mental hardships women endured were extreme and had devastating impacts on women and girls. Widows and women without breadwinners in the household were suddenly without any means of support.

By ostensibly focusing on protecting women and girls the Taliban took the position that if women's physical attractiveness - their femininity-could be hidden from the eyes of men, then men would not be tempted. The stated objective was to protect the honor of families. The Taliban's control over women included keeping them inside their houses as much as possible and restricting them from venturing outside except when in the protective custody of a male relative. Their control included keeping females out of schools and universities and out of places of business and commerce. In short, women were reduced to anonymous, faceless beings useful only to produce and care for offspring and their immediate households. Nearly all women's individual rights were drastically affected by the Taliban's edicts. The Taliban also attempted to control the lives of men and boys but to a much less degree and without taking away their core identities.

The problems faced by women in Afghanistan did not disappear with the ousting of the Taliban. Crucial problems for all members of the population continue to plague Afghans. More than two decades of war brought relentless poverty along with death and destruction. Devastated by years of war the population of Afghanistan has been driven to its knees-a poverty so intense that some parents sell their children or marry them off at tenders ages to avoid seeing them starve. A mother of six cried when she explained why she decided to give her 13 year-old daughter to be marriedthe younger children were crying themselves to sleep at night from hunger. Widespread unemployment and lack of means to acquire needed goods continues to exacerbate poverty.

\section{Initial Changes}

The immediate change affecting women and girls was the removal of the restrictions imposed by the Taliban ${ }^{1}$. Women in post-Taliban Afghanistan are free to attend schools and universities; leave their homes without a male escort; work outside the home; and show their faces in public if they choose to. As soon as the Interim Administration assumed authority on 22 December 2001 they invited female civil servants to return to the jobs they held prior to the Taliban taking control. Female employees at the United Nations and NGO agencies returned to work. Women resumed their pre-Taliban practice of interacting with male colleagues in the workplace. Beauty shops and video rental stores opened almost immediately in urban centers. Children began flying kites and drivers freely play music cassettes in their vehicles.

Some men are reacting aggressively to five years of Taliban influence and not seeing women's faces. Groups of men make remarks to women on the street and in passing cars. Even though very few women appear in public without wearing a burqa, photographs of women are everywhere, even pasted on the inside of taxis. Women are uncomfortable with men's publicly expressed attention. It will take time for men and women to adjust to the rapid social changes. The situation is different in rural communities where social interactions were not affected much by the removal of the Taliban from power.

\footnotetext{
The Taliban imposed restrictions on everyone, male and female. This report primarily focuses on women and girls, however, the attitudes and views of men and boys are equally important and affect the lives of women in important ways. Their views are incorporated into the findings of this study.
} 
A striking observation in post-Taliban Afghanistan is the failing coping strategies of many poor people. Exhausted after struggling to survive for more than two decades, many families are at the end of their ropes. It is difficult to directly link the breakdown of coping mechanisms to postTaliban and post 11 September phenomena or to the devastating drought conditions but those events are factors to weigh in the analysis.

The important point is that many people in Afghanistan are suffering badly and they urgently need assistance. Many households were dependent on remittances from relatives living abroad. Relatives sent money through hawala — an international system of cash exchange with outlets in most major cities of the world. Many hawala traders were closed after 11 September because anti-terrorist forces believe terrorists use them to move money globally. The remittances made huge differences in the welfare of people - often the difference between having food and going hungry. Many widows, in particular, depend on remittances to survive.

After the events of 11 September, people's expectations for international assistance rose. The media was partly responsible for building up people's hope. However, the expected large-scale relief to individual households did not occur in ways readily noticeable by local people. A few targeted one-time distributions of wheat by the World Food Programme in select urban centers did little to alleviate hunger and poverty conditions according to researchers ${ }^{3}$ from Tuft University Famine Center.

\section{Human Rights Violations}

Unprecedented human rights abuses during the war years were committed under the power structures of the Taliban, as well as during the mujahidin resistance to the Soviet occupation and the infighting between warlords and commanders from different groups in the $1992-96$ period. Investigations of human rights abuses to date have been seriously inadequate. Human rights reporting often lacks the critical analysis needed to influence policy decisions. Periodic reports of abuses run the risk of misinterpreting the overall picture. It is clear that in the past and now there needs to be more attention - and capacity - to address these problems. Members of the assistance community have expressed concern that human rights issues in Afghanistan are not well understood or defined. Perceptions about human rights issues in the field may differ from those noted at the international level. Available data are inadequate; therefore, collection of new data must be initiated as soon as feasible.

\section{Trafficking and exploitation of children}

While concrete evidence is difficult to produce, the trafficking of children-girls and boys-is a practice well known among child's rights organizations. Destitute parents accept money in exchange for allowing their children to go off with strangers who promise them work as domestics, camelracing jockeys or laborers. The parents believe they are acting in the best interests of their families.

In parts of southern Afghanistan young boys between the ages of 6-12 from very poor families travel on buses to Pakistan seeking work. Their journey ends at the Pirbidhai bus stop outside of

\footnotetext{
Also known as barakaats in the Middle East and in other parts of the world.

Sue Lautze, Neamat Nojumi and Fazalkarim Najimi, unpublished report on Food Security, Feb 2002.
} 
Islamabad where a commercial sex-trade, preying on young boys, thrives. The boys are targeted as they exit the buses, usually by older boys who themselves are part of the system. The new recruits are offered menial jobs in tea shops and guest houses near the bus stop. The managers of the establishments accuse the new boys of stealing; they call the police and have boys arrested. They pay a fine and the boys are released. The boys owe money that they have no means to pay. The boys are coerced into joining the sex trade network to repay the debt. Part of the indoctrination may involve an older boy raping the younger boys who afterwards are so ashamed, alone and without resources they have no choice but to join. The boys' "value" declines around the age of twelve, because the clients who frequent the establishments prefer young boys. The twelve-year olds either drift off to engage in other illicit behavior (selling drugs, stealing) or they stay on to recruit and abuse new arrivals. The clients include wealthy and middle class Pakistani men, as well as the police. Refugee boys are also lured into the illicit trade. Child protection agencies ${ }^{4}$ are trying to stop this heinous business but so far they have not been successful because of the mafia-like protection provided by the police, and probably the clients.

Public awareness campaigns about trafficking practices are urgently needed to inform the general public of the practice and to help parents protect their children. Because of the high rate of illiteracy in Afghanistan, radio public service announcements ${ }^{5}$ are recommended to convey information about the dangers of trafficking.

\section{Violence against women and girls: addressing their fears}

Following the routing of the Taliban from power media coverage showed some women throwing off the burqa - an act which gave the impression that women were ready to show their faces in public and stop wearing the all-encompassing garment. In fact, women in Kabul and Herat continue to wear burqas on the streets as of this writing. Many women interviewed said they were afraid to walk on the streets uncovered. Their reasons varied but the common response was fear "of the men with the guns". "Men with guns" refers to the former mujahidin or freedom fighters-those who fought under the commanders of the various warlords in the many phases of Afghanistan's wars. Many fighters buried their guns when the Taliban took over. As soon as the Taliban were driven out they dug up the buried weapons and some of them began robbing and looting homes. In Kabul there were over 1000 robberies in one month and a number of murders after the departure of the Taliban.

Fear is a significant feature of women's stories gathered during this research. Most women do not remember when they did not feel afraid. Their fear partly explains why women chose to continue wearing burqas even after the Taliban. Westerners have undeniably focused too much attention on the burqa issue. In the post-Taliban political climate the burqa has become a barometer of the level of insecurity women feel more than a women's rights issue.

Women report an increase in domestic violence and child abuse in recent months. Years of unemployment coupled with the hardships of war have decreased men's abilities to support their families - an obligation and honor in Afghanistan culture. Men thus affected can become depressed

\footnotetext{
4. An aid agency specializing in child protection provided the details of this account. Their organization is not referenced to protect their investigation of child prostitution.

5 An ICRC study in Afghanistan reported that approximately $81 \%$ of the population have access to radio.
} 
and angry. Some men have borrowed so much money that they stay inside their houses to avoid meeting people to whom they owe money.

I interviewed women who say that men within their households (fathers, brothers, husbands and uncles) are abusing them more than in the past. The way men view women and their right to freedom of movement has been influenced by the Taliban period. One woman said, "Many men have shaved their beards off their faces but the beards on their minds are still there." Another young woman with a medical degree from Pakistan expressed surprise that her uncle, who holds an advanced university degree and with whom she lives, in recent months has begun beating his wife frequently.

The study uncovered some extreme cases of violence against women but without more research it is not possible to know if the cases represent a trend or are isolated incidents. Two colleagues working in different parts of Afghanistan (Mazar and Herat) mentioned they too had heard about husbands who deliberately set fire to their wives (with the intent to kill). The motive may be because they are dissatisfied because their wives have not produced children. Although data are lacking, sufficient evidence exists to warrant more research. In January 2002 there were five cases of women with severe burns in Herat Central Hospital. Four were said to be self-inflicted and in one case the husband had set fire to his wife because she failed to produce a child.

\section{Advancing Women's Rights in Afghanistan}

The creation of a Ministry of Women's Affairs for the Interim Administration was a significant event that could have an important impact on the lives of women in Afghanistan. Dr. Sima Samar was selected at the Bonn Conference to serve as the Interim Vice-Chair and Minister of Women's Affairs. Dr. Samar's priorities include organizing literacy classes, returning skilled women to the workforce, and creating shelters for homeless and abused women. Dr. Samar's experience as founder of a health organization for women with clinics in Afghanistan and Pakistan put her in a strong position to champion for the rights of Afghan women.

Dr. Samar faces major challenges in establishing her office. The Ministry is new so there is no model or previous organizational structure. She sees her role as one of orchestrating gender mainstreaming into other ministries and institutions. Another Minister has already requested her advice about identifying women with management skills. Dr. Samar noted in an interview that although great changes are needed, they will take time. The Minister is well aware that to mainstream gender equity throughout all program interventions in Afghanistan, and throughout the institutional structures, major changes are needed in the social, economic, political and protection/security arenas.

In order to advance women's rights in Afghanistan advocates may have to accept incremental change - an approach more likely to result in permanent advancement and securing women's rights over time than an overt campaign to radically change social codes governing the position of women in community and family life. When it comes to social change in Afghanistan, the slate is not blank. In the past, Pashtun and other tribal revolts against the state's modernizing policies were the downfall of many Afghan rulers. When they fell, so did women's rights. Past and present conditions must be viewed realistically and analytically if meaningful and lasting change is to be realized. 
Those wishing to force rapid sweeping social changes for women may criticize the suggestion for a more moderate approach, but I would urge critics to pick their battles strategically. Most importantly, listen to the views of those who have the most to gain and the most to lose- the women of Afghanistan.

Soon after 11 September professional and educated Afghan women in a few urban centers began to meet in ad hoc groups to discuss women's participation in civil society building. The women in Herat, for example, voiced concern that too few women might be selected to participate in the Loya Jirga. Without adequate representation of women on the Jirga, the advancement of women's rights might be stalled or even moved backwards. Some educated women want to build a network of women interested in civil society building from around the country. They want to advance the rights of women in a steady forward movement but they are concerned that women from outside Afghanistan will endanger their efforts by pushing too quickly for change and set them back instead of advancing their cause.

During the Taliban period a number of women were forced to marry Taliban soldiers - in some cases educated women were married to illiterate men and very young girls were made to marry much older men. Many women who find themselves in terrible marriages have no legal recourse to obtain divorces. The Interim Administration should tackle, and push for, solutions to this and other inequitable legal issues that cause harm to women — by revising laws if necessary-to ensure that the women who were victimized by the Taliban or other military groups have opportunities to get legal redress and lead happy lives, free from their oppressors.

Some surprising positive shifts in women's thinking have appeared in post-Taliban Afghanistan. Some NGOs have reported noticeable changes in the attitudes of rural women in their program areas. One agency working in the Panjshir valley noted that women are beginning to insist on their right to participate in training and income generating schemes without the approval of the local commander or their husbands. One rural woman said the Interim Administration leader's radio statement supporting girls' education and women's rights encouraged her to speak up. Such actions are indicative of changing gender roles and increased awareness among women about their rights.

Western societies reacted strongly to the Taliban's edicts that denied women and girls access to education, and forced women who had not previously done so to wear the all-encompassing burqas. Even though they are no longer required to wear them, women have not shed their burqas. Women in all social categories fear for their personal safety. The issue of wearing the burqa is one that should be left to the discretion of Afghan women; however, their reluctance to venture out of their homes without them is an indication of their level of fear and uncertainty about the future.

\section{Food Security}

The consensus among assistance organizations consulted for this study hold that Afghans in most areas of the country do not have adequate food supplies, but in the heavily drought affected, remote, or insecure areas food insecurity is critical. Lack of food has a direct impact on women. In Afghan culture, as in most others, women are responsible for the preparation and distribution of food within the household. When food is scarce women usually eat less and last. The hierarchy of feeding in 
many Afghan homes is men first, male children, female children, elderly and last adult women ${ }^{6}$. Many elderly people survive on tea and bread. Although the number of rural villages visited during this survey was few, insufficient food was the common complaint. Weak and hungry mothers often have insufficient milk to feed their infants because of their own poor nutritional status. Early weaning practices using food such as thin mixtures of wheat-flour and water cause nutritional deficiencies. The mortality rate for children $0-12$ months is believed to be high although reliable statistical evidence is unavailable.

Agricultural rehabilitation is essential to increasing the amount of available food in the country. In the past approximately 85 percent of the population were dependent on subsistence farming, although that has changed due to the drought and years of conflict which rendered land unusable due to landmines and relocated people to various parts of the country. During the past year the drought, along with the continued effects of the war, are a primary cause of internal displacement and movement across borders. Solutions and assistance for IDPs, therefore, must include ways to help farmers produce and process food in order to increase household food supplies.

Agriculture can provide jobs for returning refugees and demobilized fighters. While some official reports claim that Afghanistan's food emergency is over, first hand observations, interviews and reports by special research teams indicate otherwise. Food insecurity in Afghanistan appears to be widespread. The World Food Programme conducted extensive house to house surveys in Herat and Kabul to determine vulnerability. They found in Herat that 78 percent of the population of the city was vulnerable and required food aid. ${ }^{7}$ A recent MSF nutrition study showed 36 percent of mothers and 10 percent of children suffered from malnutrition in Herat.

\section{Food Security Recommendations}

$>$ Assistance must focus on food production and processing.

$>\quad$ Water resource management study by expert hydrologists are needed to conserve water

$>\quad$ Rehabilitation of irrigation canals (kareezes) through food for work programs

$>$ Involve women in food production and processing income generation projects

$>\quad$ Work for cash programs to allow people to purchase needed food items

$>\quad$ Supplement the current food basket in food relief programs to add more nutrients and variety

$>$ Revive the food export sector as part of the reconstruction process (especially nuts, raisins, and dried fruit) and involve women in production

$>\quad$ Promote healthy breast-feeding practices and nutritional education programmes

\footnotetext{
6 Gender hierarchy of household food distribution varies from province to province and among different ethnic groups. World Food Programme Population of Herat City Report 03/01/02
} 


\section{Health}

The state of health care in Afghanistan is among the worst in the world. Clinics and hospitals have been destroyed or damaged by years of conflict. Facilities lack the equipment and furnishings necessary to provide even a modicum of care to patients. Poor access and inferior quality health care have long been critical concerns in Afghanistan whether in wartime or peace. Poor women cannot afford the cost of transportation to health treatment centers. They delay seeking treatment for themselves and their children until the critical stage, which is often too late. One in six children in northern Afghanistan suffer from severe malnutrition according to Medecins sans Frontiers (MSF).

The shortage of health workers stems from high out-migration of doctors and nurses during the years of war, and also fewer doctors have been trained during the years of the Taliban. Lack of skilled heath workers is partly responsible for the poor quality of health care in Afghanistan. Some dedicated Afghan doctors and nurses worked in refugee camps in Pakistan and refugee villages in Iran. Overall, few health workers had opportunities to update their skills to keep pace with the rapidly changing field. Even during the years when women were allowed to attend the medical faculty, their training was not equal to that provided for their male colleagues.

The problem is worse outside urban centers where, added to the lack of trained health workers, there is a severe shortage of health facilities, supplies, and medicine. Hospitals lack basic medicines and supplies. The few hospital laboratories equipped with blood testing equipment lack reagents necessary to perform tests. The shortage of medicines exacerbates the incidence of maternal and infant mortality. Both infants and mothers die from treatable conditions because the medicine they need is not available. Reliable statistics are lacking but maternal mortality in Afghanistan is believed to be the highest in the world. Health experts estimate that nearly half the deaths of Afghan women of reproductive health years are associated with childbirth. The health system in Afghanistan under the Taliban disintegrated from an already impoverished state as corruption, stealing and reduced external support plummeted health delivery into a system desperately inadequate to serve the needs of people.

Women have major health issues in all areas of the country. Recently at the Malalai Maternity Hospital in Kabul two women with stillborn pregnancies waited for removal of the fetuses - one waited 15 days, the other 8 days. Both women had elevated blood pressure, but because the hospital did not have medication to lower their pressure, no procedures were instigated to remove the dead fetuses. Without intervention both women could die. Clearly hospital staff need training on procedures to obtain emergency supplies of needed drugs when their stocks are depleted and on referral procedures to other hospitals. The shortage of medicines adds to the long list of causes of maternal and infant mortality in Afghanistan. Public health doctors' salaries are very low and they have not been paid in several months. Many are forced to take on other jobs to support their families. Consequently, there are few qualified doctors at the hospitals. It is possible that a qualified physician would have taken the decision to perform the procedures to remove the dead fetuses even though the women had high blood pressure. Less trained and experienced workers are reluctant to modify protocols even if not doing so results in the death of a patient.

Fatima Gul's pregnancy had been fraught with complications. Near the end of her ninth month she endured a long and painful journey from her rural home to Kabul for assistance 
with the birth only to learn that her baby was already dead. At the time of the interview Fatima had waited for 8 days for the removal of the dead baby. Another woman in a nearby bed, Homira, entered the hospital 15 days earlier to deliver her first child. Her baby was also dead and no effort had been made to remove the fetus at the time of interview.

Few healthcare options are available for people living in rural communities. Small villages generally have poor access to health facilities because of the distance to major towns. When complicated deliveries or pregnancies occur there is often nothing that can be done to save the mother and/or child. Midwives and traditional birth attendants are reluctant to report maternal and child deaths because it might appear to be their fault. In one village TBAs admitted they did not know how to report the death of a mother or child. Lack of transportation and means to communicate with health clinics, health posts and village health workers results in poor data collection and health statistics in general.

Women in most provinces express a desire for expanded family planning services. During visits to several health clinics and hospitals (in Herat, Kabul and peri-urban communities) the method of offering family planning services is by request from post-partum women. The methods preferred by women in the clinics visited were pills and injections but clinics are frequently out of stock. Family Planning counseling and improved methods of education and distribution of contraceptives is needed to better inform couples of their choices and to provide better access.

Immunization campaigns need to expand their coverage; a number of small villages do not have immunizations for their children. None of the children in Kabotar Khan, a village of 300 families near the Iran border, had been vaccinated nor were tetanus injections available for pregnant women. None of the girls in this village had attended school and few boys traveled the long distance to the school. Patients with serious illnesses or injuries go to the health clinic at Zendajan but transportation is often unavailable. The clinic is not equipped for surgery or for treatment of serious illness; such cases are referred to Herat Central Hospital.

Because of the Taliban's five-year prohibition on education for women and girls and their edicts against women working outside the home, professional schools have graduated no women doctors and nurses. An entire generation of educated high school girls who would have qualified to enter the medical faculty has been lost. Dr. Sohaila Seddiq, the Interim Minister of Public Health, is well qualified to address the need to speed up the training of women doctors and nurses. During the Taliban regime she secretly continued the women's medical faculty for a few students. Due to the Taliban's restrictions those students could not carry out the practical internship period of their training. Dr. Seddiq supports the formation of professional medical associations for both women and men. The Minister is also considering a proposal to raise the salaries of rural doctors to attract them away from urban areas where most professional prefer to live and work.

A positive effect of the changed political environment is the interest among trained health workers living outside Afghanistan to return home. Their skills are greatly needed but due to the severe housing shortage and continued insecurity in some areas their return may be postponed. Afghans living in western countries are also interested in offering their expertise in the form of short-term visits ${ }^{8}$. International organizations such as the International Organization for Migration (IOM) have instituted programs to encourage skilled Afghans to return.

8 While many Afghans who have lived abroad for many years wish to return, it will be difficult for most because they will not be able to earn comparable salaries. 


\section{Psycho-social and Mental Health Issues}

Years of coping and suffering-doing without basic necessities, losing family members, persistent hunger, poverty related illnesses, and loss of family possessions and property have caused many Afghans to sink into depression and mental illness. Depression and mental health problems are widespread, yet the public health system lacks the expertise to address the problems.

\begin{tabular}{|l|}
\hline \multicolumn{1}{c|}{ Health Sector Recommendations } \\
$>\quad \begin{array}{l}\text { Rebuild, staff and supply health facilities. Recruit and train more health professionals to } \\
\text { support women's health recovery. Permit male doctors to treat women as the need demands. }\end{array}$ \\
$>\quad \begin{array}{l}\text { Increase training of traditional birth attendants (TBAs), nurses and female village health volunteers. } \\
\text { family planning; sexually transmitted infections treatment, testing and education. }\end{array}$ \\
$>\quad \begin{array}{l}\text { Provide accelerated preparation programs for nursing and medical school students to } \\
\text { compensate for the Taliban's ban on female education. }\end{array}$ \\
$>\quad \begin{array}{l}\text { Increase mobile clinic coverage in rural villages, especially for immunization and women's } \\
\text { health programs. }\end{array}$ \\
$>\quad \begin{array}{l}\text { Establish small community-run village health maintenance centers in remote areas. Use } \\
\text { village centers for community events as well as for mobile clinic visits. }\end{array}$ \\
$>\quad \begin{array}{l}\text { Establish a national professional medical association for women doctors of Afghanistan } \\
\text { to facilitate linkage to international health professionals for the purpose of compensating } \\
\text { for inequities in professional development and recognition. }\end{array}$ \\
$>\quad \begin{array}{l}\text { Institute psychosocial/mental health services as part of regular health care; provide technical } \\
\text { expertise to build capacity of Afghan staff through training of trainers. }\end{array}$ \\
$>\quad \begin{array}{l}\text { Expand tuberculosis treatment program for women and promote TB awareness and } \\
\text { prevention campaign; support nationwide survey of cases disaggregated by gender }\end{array}$ \\
\hline
\end{tabular}

\section{Young Afghans}

Young people may be the most severely affected social group of the Afghan war. Life for them has only been war. Focus groups and interviews with young boys and girls revealed mistrust of leadership and strong desires not to become leaders. During a focus group with boys ages 15 and 16 the researcher commented that the participants were the future leaders of Afghanistan. Looks of concern showed on their faces. One said, "I never want to be a leader. They are bad people." Another said, "People don't like leaders. They get killed. I just want to have a good career." Girls had similar reactions. The girls were asked what they thought about the Interim Administration having two women ministers. The girls felt they were not like ordinary women and did not represent role models for them. The girls expressed their interests in having careers and were extremely happy that they would now be able to attend school. 
The girls expressed more optimism than boys. The boys seemed to be under more pressure and worried that they would not score well on their placement tests. Several of the boys in the focus groups admitted to being depressed and discouraged about their future. The majority of boys interviewed had fathers who were unemployed ( 90 percent.) Families were suffering due to poverty. The depressed boys described feeling that life would not be good for them. Most understood that they would have to work to support their families and would not be able to advance their education beyond secondary school because of the need to earn wages.

\section{Education}

The long-lasting effects of the ban on education of girls are impossible to assess. Afghans I interviewed for this study held strong views on education. Across age, class and ethnicity women (and men) want education for their children. Many small villages of 300 or so households often have no school within walking distance and no means of transportation for children. In several villages I visited for this study none of the women or girls had ever attended school and only a few of the boys and men had done so. The desire for education, however, was high. Women focus group participants said their husbands agreed that daughters should go to school. The limiting factor was the availability of schools within walking distance to homes. The recent change in government and removal of the Taliban's edicts against education for girls has had an immediate and positive effect on the attitudes of Afghans about education-now that it is possible, most families feel it is a positive option. That said some families would likely choose to send boys to school and keep girls at home to help with household chores. As one mother put it: "why waste time, my daughter will marry soon and until then she can help me at home with the other children."

The community-based schools that parents and NGOs started during the Taliban can continue to serve important roles in small communities by allowing children to be educated within their own communities. UNICEF and Save the Children USA have developed effective core competencybased education materials that are applicable to one or two room school-house environment.

\section{Education Recommendations}

$>\quad$ Classroom schedules need to be flexible to accommodate children who must work to help their families.

$>$ Expand and support community based schools in rural communities.

$>\quad$ Accelerated programs and special curricula appropriate to age groups and changed social circumstances are needed.

$>\quad$ Provide special education programs to meet the needs of girls and boys who have missed out on five or more years of education.

$>$ Revise curricula to educate boys and girls on the importance of gender equity.

$>\quad$ Expand teacher-training programs. 


\section{Internally Displaced Persons and Refugees}

Approximately five million Afghans are internally displaced or are refugees. Nearly one million are displaced within Afghanistan-a large proportion is women and children. The impact of a largescale refugee return will likely be significant. Some refugees are eager to return home while others prefer to wait and see how stable the government will be especially after the Loya Jirga selection process that will take place in June 2002.

IDP and refugee camps provide little security. Violence in the camps increased between ethnic groups after the Taliban were driven from power. Women have been raped in the camps in Mazar and Herat according to relief agencies. The International Rescue Committee has documented over 60 cases of sexual violence against women in a Mazar IDP camp. Most IDPs live in miserable conditions. The distribution of food and other items is not on an equitable basis. Women and vulnerable groups often do not receive their correct allotments of food. Displaced women do not have a voice - they are not represented in camp leadership committees, so their problems and needs tend not to be known.

A joint statement ${ }^{9}$ by Medicins sans Frontier and Medicins du Monde reported that the nutritional status of long-term IDPs at Maslakh camp was worse than for new arrivals. That finding suggests that the IDPs are not receiving enough food. The agencies reported widespread corruption and criminal activities in the camps especially linked to food distribution. Conflicts between ethnic groups, especially between Pashtuns and Tajiks have intensified and resulted in several deaths.

Nomadic Koochi populations lost significant numbers of their animal stocks due to the drought and have become destitute. Koochis have settled into the IDP camps. They have become the target of non-Pashtun IDPs in the camps because the Koochis were well treated by the Taliban.

\section{Recommendations for Internally Displaced Persons}

$>$ Promote and assist in the return of IDPs to their home areas as soon as possible.

$>$ Restock animals for the Koochi community so they may return to normal life patterns.

$>$ Implement a gender-based violence prevention program in the camps to raise awareness.

$>$ Expand protection services and security in the camps.

$>$ Provide income generating and skills-building activities for women in camps and upon return to home areas.

$>$ Survey households to determine food security and nutritional status.

$>$ Agencies collecting data should distribute findings to all agencies working with IDPs.

9 MSF and MDM presented Mrs. Ogata with their written statement about conditions at the camp during her January 2002 visit to Herat on behalf of the Japanese government. 


\section{Security}

Discussions about national security dominate the daily conversations of Afghans. The worst destruction to Afghanistan and to civilians occurred during 1992-1996 when the commanders and warlords brutally fought after the Soviet forces withdrew. People are afraid of robberies and assaults. Those who can afford to, install iron bars on the windows and doors of their homes for protection. I asked a woman with three small children about the security in her apartment block in Kabul. She replied that it was safe because the front door of the building was locked at night and only one person kept the key.

I asked what she would do if an emergency occurred and she needed to get out of the building when the gate was locked. She said the tenants in the building decided that the chances of them being robbed were greater than having an emergency.

Are women's fears well grounded? A UN head of agency commented that security forces have not reported cases of violence against women in Kabul. It is not surprising that no cases have been reported even if they have occurred given that uniformed men in the ISAF collect the data. In the Afghan culture a woman, or her male relatives, would not report an incident of gender violence to a male soldier. Women do not have ways to report abuses in a confidential, appropriate manner.

\section{Prospects for Gender Equity and Progress by UN agencies}

In January 2002 Interim Administration Chairman, Hamid Karzai, signed the Declaration of the Essential Rights of Afghan Women. The declaration ${ }^{10}$ states that there is "equality between men and women, equal protection under the law, institutional education in all disciplines, freedom of movement, freedom of speech and political participation and the right to wear or not wear the burqa or scarf". The Chairman's statement is an excellent starting point for improving gender equity in Afghanistan. To institutionalize gender equity each Ministry should be responsible for ensuring that the Declaration is enforced.

Much of the weight of advancing gender equity falls on the Minister of Women's Affairs. United Nations agencies, in particular UNIFEM, UNICEF, UNESCO and UNFPA, seem to be stepping up to the plate to support the Ministry of Women's Affairs and the objective of improving women's rights. International and local NGOs have likewise taken steps to support the process of recovery from the repressive years of the Taliban. Donors are also offering unprecedented support to assist women and girls and to promote gender equity. Coordination among all actors promoting gender equality is key to achieving the goals.

The Interim Administration has pledged to carry out the Bonn Agreement, which makes little reference to women except to state that women should have significant participation in the Loya Jirga. Also, the IA identified key priority areas for the reconstruction of the country-education, especially for girls, was noted as a priority.

10 For the statement see Center for Humanitarian Cooperation website: www.cooperationcenter.org/library4.asp 
Aid agencies have traditionally applied the Women in Development (WID) approach in Afghanistan as opposed to Gender and Development (GAD). The difference lies essentially in programming specifically for women-WID versus GAD that attempts to tackle the root causes of inequality and tries to change social practices and attitudes about the unequal treatment of women. Programming for women has been more culturally acceptable in Afghanistan in the past. In fact, under the Taliban only projects that related directly to health could be carried out for women. With the Taliban presumably out of the picture it remains to be seen whether or not Afghanistan society is ready for the more challenging Gender in Development approach which will require a willingness to address some of the old patriarchal practices of male dominance.

UNIFEM with several partner organizations (UNFPA, ILO, PARSA and bilateral agencies) and the Minister of Women's Affairs sponsored a two-day consultative meetings in Kabul prior to the annual March 8th International Celebration of Women's Day. The objective of the meetings is to support women's leadership in peace building and reconstruction and increase the participation of women in Afghanistan.

A paper co-authored by the UNDP and the World Bank, for the Tokyo Conference on Afghanistan Recovery and Reconstruction: Gender as a Cross-cutting Issue ${ }^{11}$, presents options for mainstreaming gender in Afghanistan in each sector. The authors acknowledge the importance of understanding the Afghan context influenced by patriarchal attitudes.

\section{Conclusion}

The most effective and lasting means of putting Afghan women in charge of developing their own gender plans of action is likely to be through local institutions, including women's organizations and associations (many are newly formed) and by giving Afghan women support to develop their own programs for gender equity. International organizations, the United Nations agencies, donors, and NGOs can advance women's interests by applying a gender-mainstreaming approach in all programs and policies. Moreover, by setting examples by hiring women in decision-making capacities, the international agencies can strengthen the positions of Afghan women.

The turbulent political history of Afghanistan attests to the power given to control over the women and women's comportment-including veiling and unveiling. Afghan women who have lived inside Afghanistan during the long years of conflict well understand the risks of pushing too fast towards gender equality in their society.

The international community, eager to support the achievement of equal rights for women in Afghanistan, must keep vigilance over human rights issues in Afghanistan and be quick to point out violations and trends that might lead to abuses. Moreover, Afghan men and women are depending on international support for enhanced protection and enjoyment of their rights.

Afghan women can develop their own version of a gender equity framework to apply to the recovery of Afghanistan. International support can be most constructive by supporting Afghan women in

11 Nassery and LeDuc, Afghanistan Recovery and Reconstruction Preliminary Needs Assessment, World Bank and UNDP. January 2002. 
developing leadership skills and in material support to facilitate their accomplishing goals they set for themselves based on their perceptions and experiences.

What changes have taken place in Afghanistan since 11 September that affects the lives of women? It is difficult to know what is the effect of long range conflict, what is the effect of the unseating of the Taliban, the presence of the new authorities, including the more dominant United Front forces (formerly Northern Alliance), and what is the result of wider ongoing processes of social change. What seems clear is that women are being extremely cautious, but at the same time they are optimistic about the future. Most are taking a "wait and see" attitude regarding personal safety and taking off the burqa in public.

Afghan women will best make key decisions about reconstruction and recovery and the role of women in Afghanistan. The international community can, however, facilitate the environment in which Afghan women can make those decisions.

International agencies must work hand in hand with Afghans to protect and promote the human rights of women and to ensure that they play a key role in the structuring and maintenance of peace. Solutions to the problems women and girls face will come by mainstreaming gender issues in every aspect of social, political and economic life in Afghanistan.

Rights-based humanitarian action and development programming highlight the importance of countering the discrimination and marginalization that is largely responsible for the suffering and deprivation in the lives of the vast majority of women and girls in Afghanistan. 


\section{References}

Afghanistan Humanity Denied: Systematic Violations of Women's Rights in Afghanistan, Vol. 13, No. 5 C, Human Rights Watch, October 2001

Afghanistan Recovery and Reconstruction Preliminary Needs Assessment: Gender as a Crosscutting Issue, Homaira Nassery, World Bank and Carol Le Duc, UNDP, January 2002

Blind Chickens and Social Animals: Creating Spaces for Afghan Women's Narratives Under the Taliban, Anna M. Pont, August 2001, Mercy Corps, Portland, OR

Center for Humanitarian Cooperation www.cooperationcenter.org/library4.asp.

Emergency Food Assistance to Afghanistan, EMOP 10155.0 (revised January 9, 2002) UN World Food Programme Document.

Monitoring the Situation of Returnees in Afghanistan, Summary of Findings January to July 2001, UNHCR, OCM Afghanistan

Poor Rights Record of Opposition Commanders, Human Rights Watch, October 6, 2001.

Women's Health and Human Rights in Afghanistan: A Population Based Assessment, A report by Physicians for Human Rights, 2001, Boston, MA

World Food Programme Afghanistan Vulnerability Analysis and Mapping Unit, Food Security Assessment, July-August 2001 


\section{Organizations and individuals consulted}

ACTED (Agence d'Aide a la Cooperation Technique et au Developpement)

Agency for Rehabilitation \& Energy-conservation (AREA)

ARIANA Vocational Training for Women

Coordination of Humanitarian Assistance (CHA)

DACAAR (The Danish Committee for Aid to Afghan Refugees)

Danish Afghanistan Committee (DAC)

International Committee of the Red Cross (ICRC)

International Medical Corps (IMC)

International Office of Migration (IOM)

International Rescue Committee (IRC)

Medicins du Monde (MDM) Medical Coordinator

Mercy Corps International (MCI)

Norwegian Afghanistan Committee

Oxford Development Consultants (consultants to the World Food Programme)

PARSA Afghanistan

Save the Children, USA

Swedish Committee for Afghanistan

United Nations Centre for Human Settlements (Habitat)

United Nations Children's Fund (UNICEF)

United Nations Coordinator's Office (UNCO)

United Nations Development Programme (UNDP)

United Nations Educational, Scientific and Cultural Organization (UNESCO)

United Nations High Commissioner for Refugees (UNHCR)

United Nations Population Fund (UNFPA)

UN World Food Programme

UN World Health Organization

USAID/Office of Transitional Initiatives (OTI)

US State Department, Refugee Coordinator

World Bank

Afghan Interim Authority representatives and others

Dr. Ashraf Ghani, Brahimi Group

Dr. M. Popal, Deputy Minister of Higher Education

Dr. Sima Samar, Minister of Women's Affairs

Dr. Sohaila Seddiq, Minister of Public Health

Mr. Said Mohsen Samemi, Regional Officer Ministry Martyrs and Refugees 


\section{Annex B}

\section{TERMS OF REFERENCE}

\section{STUDY ON THE SITUATION OF WOMEN AND GIRLS IN AFGHANISTAN}

Since the adoption of ECOSOC Resolution E/CN.6/2001 (March 2001) on discrimination against women and girls in Afghanistan, much has changed. Events since 11 September - culminating in the end of Taliban rule and the appointment of a new Interim Administration - have drastically shifted the national political landscape. This changed environment provides new opportunities to tackle the problems, including discrimination, suffered by Afghan females. However, many problems of the past remain.

Longstanding insecurity, a legacy of many years of war, remains a defining feature of many parts of rural Afghanistan. Significant displacement continues to occur and add to the existing large numbers of vulnerable Afghans both in and outside the country. While humanitarian access to the main cities is now almost complete, the capacity of the international community to reach war- and drought- affected vulnerable people beyond the cities has been severely curtailed by war, as well as by the onset of winter.

The ECOSOC resolution called for regular reporting to the Commission on the Status of Women on progress made in its implementation. In order to complete a new report, there is, first, a need to analyse how events of the past few months have affected women and girls.

\section{Purpose:}

- To determine the impact of events since 11 September on women and girls

- To better understand the prospects for gender equality under the newly installed Afghan Administration.

\section{Issues to Consider:}

\section{Situation:}

- What has been the impact of the conflict in recent weeks on the lives of women and girls?

- $\quad$ Any evidence of changes in gender roles as a result of conflict?

- Changes in the nature and incidence of violence against women and girls?

- Impact on womens' economic status? (loss of assets etc)

- How has the change in political power affected the situation of women and girls?

- Early indications of repeal of discriminatory laws imposed by the Taliban?

- Trends in violence against women as areas change hands and greater stability prevails? 
- Changes in access to health, education and employment outside the home

- Increased participation in public life

- Greater freedom of movement?

- Population movements: what are the gender dimensions of the displacement since 11 September, and before, due to drought (gender composition of IDP groups, gender roles in IDP settlements, obstacles to return - for women and men).

\section{UN response:}

- $\quad$ Progress made by key UN operational agencies and NGO partners in integrating gender into programming over the past year

- Identify examples of responsiveness of UN programs to any newly emerging needs as a result of the conflict and displacement from both drought and conflict

- Identify key agency programs which are actively working to end discrimination in Afghanistan and to promote women's rights

- Progress in recruitment of female staff

\section{Methodology:}

Review of key documents produced in the past 12 months (including, for example, recent SG and other such reports, relevant studies, papers etc)

Consult, with the assistance of an Afghan colleague, with:

- $\quad$ key individuals and agencies focused on the situation of women and girls in Afghanistan;

- $\quad$ key UN agencies (particularly WFP, UNFPA, UNHCR, UNCO, UNSMA, UNICEF, and FAO), international organizations (IOM, ICRC) and selected international and national NGOs to identify effective strategies to further gender equality in Afghanistan;

- a small cross-section of Afghan women and men and young people

\section{Output:}

Provide a draft Report to the UN Coordinator for review before finalization within the stipulated timeframe. 
